\title{
Foregrounding of War as a Socio-political Issue in Hamid Khan's Poetry
}

* Abdul Karim Khan, Assistant Professor (Corresponding Author)

\begin{abstract}
Hamid Khan uses the tools of foregrounding (deviation and parallelism) to project war and its devastating effects on society. This paper aims at searching for the projection of the theme of war through deviation and parallelism in the two poetic collections of Khan, i.e. "Velvet of Loss" and "Pale Leaf(Three Voices)". The data are analysed on the basis of the theory of foregrounding. Apart from the apparent reference to war zones, the implications of the horrors of war, at global level, are found. These devastating effects include hopelessness, insecurity, homelessness, losing of the near and dear for ever leaving behind orphans, widows, and patrons.
\end{abstract}

Keywords: Foregrounding, Deviation, Parallelism, War, Hamid Khan.

Introduction

War as a socio-political issue on the world level is devastating and causes serious threats to the overall uplift of the society, though despite its well-known consequences, the nation-states are involved somehow or the other in war with one another on one pretext or the other. Khan's sensitive mind has captured the horrors of war implicitly and indirectly with an economy of words in the following poems: The Walls, Window, April Symphony, By the Nile, The Martyr, Africa, Africa - II, Bosnia - I, and Bosnia - II.

Hamid Khan (2016) expresses his views on the concept of war and its effects on the society implied in literature of colonial era with specialist reference to Rudyard Kipling's works which he terms as politics of aesthetics. He maintains:

"The British went to war with Afghanistan in 1838, 1878 and 1915 respectively to ensure that it remains in its specific sphere of influence. The same is also true of Tibet and the Kashgharia which territorially lay within the Chinese fold despite the British Tibetan expedition in 1858. Russia's colonization of Central Asia, during the latter half of the 19th century, was drawn by the same colonial commitments and exigencies as its rival Britain." (P. 69)

Alyssa Ayres (n.d) considers Kashmir as the bone of contention between Pakistan and India which have caused the three main wars of 1947, 1965 and 1999, apart from the routine skirmishes on the lion of control. She mentions the efforts from both sides to keep peace at pace but soon after the peace process, belligerency starts afresh. She further maintains that the tension between the two neighbouring countries resulted in the postponement of the summit of SAARC in 2016 as India, Afghanistan and Bhutan boycotted to attend the summit on the assumption that Pakistan supports terrorist activities in India.

Similarly, war on terror has caused the Pakistanis and Afghans terrible losses in terms of man power and, casualties, and collateral damages. Ramesh Thakur (2012) disseminates the information that war on terror have resulted in killing of the 3000 Pakistani soldiers apart from the 40,000 loss of lives in US drone, and reactive suicidal and other aggressive attacks from the side of the militants. The newspaper, The Nation (9 Oct, 2012), comments on the situation that due to terrorist attacks people have terrified to the extent that nobody knows as to whether or not they will return home safely after they have gone away. Every sane person has the idea that the drone attacks result in civilian casualties too which in turn leads to reaction on part of the bereaved; hence the nation has witnessed the alarming grown in terrorism in the last decade. Abbas (2011) also agrees to the fact that drone attacks lead to the growth of terrorism and not the vice versa. In this connection, Sajjad Malik (2012) quoted in Umbreen and Ali (2013) avers that terrorism has caused serious uncertainty in the minds of the people of Pakistan. No matter where it is, terrorism disrupts and fragments the society and curbing it through less judgmental and less humanitarian way leads to production and the

* Department of English \& Applied Linguistics, UST, Bannu, KP, Pakistan Email: akarim.khan@ yahoo.com 
reduction of it. This fact was accepted, later on, by the Coalition forces too and they desired a peace talk with the Taliban. Pakistan too tried to eradicate militancy that was caused by the Afghan Taliban inside Pakistan. (Haque, 2012). In this regard, Zafar Nawaz Jaspal (2010) comes uop with the solution to eradicate militancy and terrorism that in addition to military tactics, seeks help from non-military approaches. Suspicion is created through various means such as polio vaccination. In this connection, Umbreen Javaid and Zulfiqar Ali (2013) quote Imtiaz (2012) and Ahmad (2012) as stating that with respect to the growing terrorist attacks and the doubts about polio vaccination in Pakistan, the UN agencies stopped the process of vaccination for the time being.

In addition, Francis Fukuyama (1982) gives a detailed account of the repercussions of war resulted in the Soviet invasion of Afghanistan in 1978. He states that cross-border infiltration between Pakistan and Afghanistan occurred by the nomads called pawindas even before the war for migrating to better place during climate change. But this migration was aggravated during Russian invasion of Afghanistan, as the people of Afghanistan mostly adjacent to the borderline fled to Pakistan for seeking refuge. This caused huge burden on the economy of Pakistan. He concludes that for Pakistan's stability, it is highly required for Pakistan to curb domestic instabilities as it directly affects foreign relation of the country. For this purpose, the tribal leaders both in Baluchistan and NWFP (now Khyber Pakhtunkhwa) should be taken into confidence. The Zia regime that caused great hustle and bustle in the political scenario of Pakistan, as it witnessed the once most popular party PPP leader, Zulfiqar Ali Bhutto, to be hanged. The Russian-Afghan war and the consequent civil insurgency that led to the rule of Taliban caused Afghanistan to bear the brunt of severe poverty, and lack of basic amenities of life. Karim (2017) describes the event of 9/11 as a blowback of Cold-War policies with respect to Afghanistan. He further adds that Pakistan was beguiled to plunge into the war on terror because of the Indian interest in the war that was deemed threatening to the security of Pakistan.

Mohammad (2016) in his Instability in Afghanistan: Implications for Pakistan argues that a New Great Game has been started in Afghanistan by US Coalition forces. In this connection, he agrees with Saleem Safi (2013) who termed it Buzkashi, a game being played in Afghanistan since time immemorial and in which the dead goat becomes the bone of contention among the players. Definitely, such Great Games will and is threatening to Pakistan too due to her strategic importance in the region. The effects of this tug of war directly and indirectly affect Pakistan.

\section{Research Objective}

The purpose of this study is to bring to the surface the devastating effects of war that are implied in the poetry of Hamid Khan through the tools of foregrounding.

\section{Research Question}

The study is guided by the following research question:

How is war projected as socio-political issue in the poetry of Hamid Khan?

\section{Method}

Lesley Moss (2014) quotes Martindale (2007) as saying that foregrounding is chiefly sub-categorized as deviation and parallelism. Van Peer and Hakemulder (2006), and Shen (2007) also classify foregrounding into deviation and parallelism. After having analysed all the poems of Hamid Khan through the tools of foregrounding i.e. deviation and parallelism, the theme of war is projected in nine poems in addition to the code-switched phrase and word. The poems include: The Walls, Window, The Martyr, Africa, Africa - II, Bosnia - I, Bosnia - II, April Symphony, and By the Nile. Moreover, the theme of war is also foregrounded through the code-switched word, Swastika and the phrase, Ku Klux Klan.

\section{Analysis}

The horrors of war are projected by Khan in the poem, The Walls, through the adjectival phrases, the crumbling walls, and cold iron. Moreover, through the metaphors of bird and the cold iron aggravate the idea of war as it highlights imprisonment of the innocent people. The devastating effect is also provoked through the repetition of the phoneme, /t/ that reminds us of firing and shooting and the continuity of war is foregrounded through the repetition of $/ 1 /, / \mathrm{m} /$, and $/ \mathrm{n} /$.Thus the walls of misunderstanding and intolerance will lead to bloodshed only.

The poem, Window, too carries the message of the ugliness of war. Khan has dexterously manipulated, here, the language and repetition of the sounds thereby bringing to the surface his desired theme - the war and the horrors of war. Through the noun phrase, ahuman voice, he attracts 
our attention as to what is hidden in the human voice. Whether this is really a voice or vice that he wants to convey? Similarly, the first strophe carries syntactic deviation by lacking verb that foregrounds the standstill situation, which in turn leads us to believe that there must have happened something terribly wrong that has caused such pin-drop silence, but at the same time, ironically, we hear the first song first the youth's mouth. So, the song can be taken the last words of the youth who may have given life to fighting with his opponents. This is confirmed through the use of oxymoron, visible darkness. The presence of the darkness all around is supported by the anagram that is made as a result of combing the repetitive sounds thus giving us zipping liting (lighting). Hence, the presence of overwhelming darkness and the only human voice give horrifying effect that can only be possible in the days of war. It also takes to believe that the whole city, or village has been crumbled down - it is a menace; it is a vice.

The Martyr gives the clear picture of war which is specifically related to the Muslims of Philistine. The title of the poem makes the martyr definite thereby foregrounding the idea that they are fighting for a just cause, that is why there number is increased day by day which is projected through hoist, which is normally collocated with flags, hence it also highlights another notion that these philistines go to war for protecting their true identity. Moreover, Khan introduces the martyr directly while keeping the name unrevealed thereby giving the idea that they are very many and each day they are being killed at the fronts. This lifelong struggle does not come to an end; they will fight with the Israelites forever and forever, unless some peace agreement is not materialized by the world super powers. Khan maintains the effect of continuity of war through the alliteration of /t/ sound connotes firing and shooting. Moreover the alliteration of $/ \mathrm{w} /$ connotes woe and worries of the people who lose their near and dear ones in war. Khan maintains a relaxing effect with the assonance that corresponds to the fighter's feelings of satisfaction but he turns this relaxing feeling into harsh and dissatisfactory ones by the alliteration of /w/ that connotes woe and worries of the family members of these martyrs.

The conflict that is going on in the Arab world is summarized in the Question About Islam website (2007 - 2018) in these words:

"During the First World War, the Ottoman Empire, which ruled Palestine and most of the Middle East, sided with the Germans. In December of 1917, the British captured Jerusalem and by 1918 all of Palestine fell under British rule. In 1917, British Foreign Minister Arthur Balfour issued the "Balfour Declaration of 1917", promising to establish a Jewish state in the land of Palestine for the first time in over 2000 years." (Para 8)

The same website further gives the detail of the revolts of 1963 and 1987 led by the Arab Muslims. The latter revolt is known as "The Intifada" which lasted for six years and which paved way for severe punishments of those who revolted.

The Oslo peace agreement of 1993 between Palestinians and Israel was the outcome of the peace process after the 1990 Gulf War. In this way, the Palestinian government was established.

Moreover, through the twin poems, Africa and Africa - II, Khan brings to the surface the subhuman condition of the African people spreading over the vast 52 countries on the map of the world. The very word Africa takes us to travel in the poverty and war stricken people who were being sold out, like animals, to the rich of the world for doing drudgery while receiving nothing of value in return.

Khan projects the poor human condition of the Africans by telling the story of a man who is both crippled and beggar and who is being helped by some coins. This is followed by the eye-opening word, savior that foregrounds that it is not the matter of some coins that are thrust into the hands of the beggar, rather some remedial measures must be sought so that the below-the-poverty-line condition of most of the African could be uplifted. Moreover, he maintains the effect of the bereavement through the capitalization of the phrase, ARMED RACE. This highlights the idea that to inflict war on a nation that is already standing on the verge of annihilation is the peak of cruelty. Kate Humble (2013) an English traveler, often visits such areas where life has become hell. In one of her YouTube videos, She visits Maluku island which was famous for its spices and which was once raided by the Dutch and the English for maintaining monopoly over the rich spices of the area. These colonizers killed so many of the chieftains of the locality that the bereaved ones are still shedding tears. Such stories of genocide are in thousands to hear and watch. Khan shows his disgusting feelings about the cannibalistic attitude of man towards their fellow beings through the use of oxymoron, 
stupid optimism and the simile, crouching/like a dog. This type of feelings are further provoked through the alliteration of $/ \mathrm{k} /$ sound and the consonances, $/ \mathrm{t} /$ that projects the last breath of an injured person due to shooting.

Similarly, Africa - II too depicts the same bloody picture of the Africans. Khan provokes our attention by the semantic deviation in the noun phrase crowd of bones that suggests lack of identity due to genocide and mass murders, even more so the burial is done late/in the dusk thereby giving us the idea that they are so much terrified that could not dare bury their dead ones in public and in broad day light. Again, in this poem too, Khan tries to focus our attention on the horrors of war by employing consonance sound, /t/ that leads us to the battle field where shooing is normal routine activity. Sylvie Kande (2018) expresses her feelings over the mass killing in Africa and resultantly the power shift there:

"The 1994 genocide in Rwanda coincided with the first nonracial elections in South Africa. For all its horror, it has shifted the study of conflicts in Africa... to their real causes that generally stem from larger economic, political, and environmental issues, including tensions due to disputed access to scarce land resources." (para 3)

Khan extends the theme of war to the twin poems Bosnia - I and Bosnia - II, where he employs various tools to attract readers' attention and to compel them to reach the message. The explicit reference to ethnic cleansing is a sort of tribute to the courage of the dead Bosnians as they showed a lot of courage and resilience to retain their identity and by doing so lost their lives too while leaving a train of living family members in a world of chaos and destruction. The phrase, dead Bosnians also gives the message that the living conditions of the Bosnians is so pathetic that being dead is more attractive than being alive. Through the semantically deviant phrase the forehead of the world the message of fabricated stories of legalizing the atrocities done to the Bosnians is projected which is further supported by the crumbling myths. The horrors of the situation are foregrounded through lengthening shadows of pain.

Khan uses the sounds through which he drags our attention to the gravity of the situation. The repetition of $/ \mathrm{s} /$ sound and the nasal sound $/ \mathrm{m} /$ remind us the sounds that are uttered when someone is being silenced in order to conceal their presence which normally happens during war. Besides, the repetition of $/ \mathrm{k} /$ and $/ \mathrm{d} /$ sounds suggests the sounds of dragging the charging handle and pulling of the trigger of a gun respectively.

Moreover through the code-switched phrases, Khan makes us focus our attention on the Great Games or the spy war launched by the super powers of the world. Ku Klux Klan refers to "the secret hate group sponsored and founded by America in 1915 in order to carry out her heinous designs against certain ethnic groups, especially the Muslims and black people and foreign individuals." (www.dictionary.com ). Similarly, the word swastika is Sanskrit that means well-being. John Black (2014) gives us the following details about Swastika:

"The earliest swastika ever found was uncovered in Mezine, Ukraine, carved on an ivory figurine, which dates an incredible 12,000 years, and one of the earliest cultures that are known to have used the Swastika was a Neolithic culture in Southern Europe, in the area that is now Serbia, Croatia, Bosnia and Herzegovina, known as the Vinca Culture, which dates back around 8,000 years."(para 5)

He further quotes a Sanskrit scholar P.R. Sarkar as saying that the underlying meaning of the word is 'permanent victory' and "in Hinduism, the right-hand swastika is a symbol of the God Vishnu and the Sun, while the left-hand swastika is a symbol of Kali and Magic." (para 6)
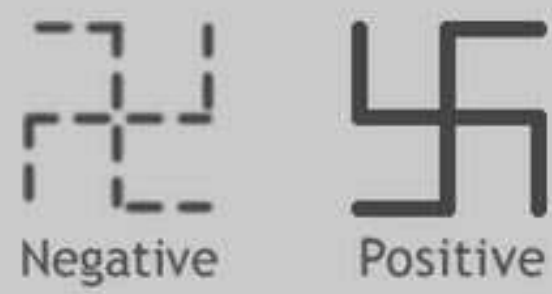

Thus, through the above foreign words, Khan foregrounds the origin and nature of the conflicts among the various ethnic groups and religions of the world. It is this difference of opinion and intolerance that lead to bloodshed of humans. Such tensions are routinely observed as Lampe 
(n.d.) states that the independence of Bosnia and Herzegovina recognized by the United States and the EC led to the attack of the Bosnian Serb paramilitary forces on Sarajevo. Moreover, it also resulted in expulsion of the Bosnian population that was termed as ethnic cleansing.

After describing the devastations of war in Bosnia in the poem Bosnia - I, Khan comes up with foregrounded lesson of courage and forbearance to the people of Bosnia in the poem Bosnia-II. Through the noun phrase, little baby, the idea is given that the orphans remain while their elders are dead. Through the use of metonymy, sky, he invites the young ones to muster of courage and start life fresh zeal. To teach hope to a child foregrounds the idea that people during bad days are so much disappointed and disheartened that they cannot understand simple truths and facts about life. The syntactically deviated line in the first strophe suggests that in time of war there is rule of lawlessness; everything is bungled up; everyone is confused; everyone becomes a child who does not use sense but only cries. Moreover, the entire poem lack repetition of phonemes (Khan's poems often carry such repetitions) which foregrounds that there is no repetition of the war story rather everyone has their own story of sufferings.

The sufferings of the people of Bosnia and Herzegovina are basically due to the multiethnic way of life. There are Croats (Catholics), Serbs (Orthodox), and Muslims living there, hence it becomes very difficult for the students in the educational institutions to come to an agreeable point, especially in the history class and that is why the subject of history has three different versions of it. (DW Documentary, 2018). A ray of hope is felt now as the young generation does not like to be separated by the concrete pillars raised by the school authorities. (ibid).

Khan in his poem, April Symphony compels us to think as to what will come after, Perhaps! through the noun phrase, Remade world, he foregrounds the idea that war has turned the whole city or area into debris. That is why the people are sick and tired of wars as is projected through the noun phrase, broken men. This is applicable to the afghan-Russian war as well as war on terror with reference to Afghanistan and FATA where war on terror is going on. Moreover, the annoyance and hopelessness of the war stricken people are foregrounded through the use of question and exclamation marks in the second strophe and their lack of movement towards their once left houses and the city is foregrounded through the lack of verb in the same strophe. The personification of the April breeze provides a ray of hope for these displaced people. This idea is further strengthened through productivity of the earth.

The parallel phonemes (/n/, /i:/, /z/, /d/, /s/, /t/)can be anagrammatized as "neat days" thereby giving the idea that everything has got normalcy, though the devastative effects were so alarming that it shook the very belief in peace of the people.

By the Nile projects the message of human conflicts since long. The very title takes us to the rich Egyptian civilization and the pomp and show of the Pharaohs but it also provokes us to think of the downfall of these people due to their arrogance and haughtiness. Through the deviational words and phrases, Khan brings to the surface all this. The assonance and consonance (centuries of nostalgia) that often come together in this poem suggest the amalgam of both relax and tense moods of the poet as well as the ups and downs experienced by the countries along which the Nile flows. This implies the clashes between the poor and the rich, between the good and the bad, and between the haves and have-nots. The noun phrase, the beat of dream, foregrounds that the dream of peace and prosperity will hopefully be materialized, though at present it is not the case. Khan sketches the current scenario of the African people through the transferred epithet in the phrase languid air.

\section{Conclusion and Discussion}

Apparently Khan has restricted the horrors of war to some of the hot war zones of the world such as Bosnia and Herzegovina, Philistine, Afghanistan to mention a few, but it can give meaningful implications of the devastation caused by war in the context of wars in the South Asia, especially the conflict going on in Kashmir and the tussle between the opposing forces in Afghanistan. One story goes that hundreds of Russian soldiers are still missing among them some are recently known who raised their families in Afghanistan. They have converted to Islam. A Russian photographer, Alexey Nikolaev (2015) wrote in his Forever Captive (Russian Afghans) that there are some 500 soldiers held captive but they have assimilated to Afghan way of life - they have raised family from Afghan women. Khakimov, now Sheikh Abdullah, is one of them who says that he was injured and was taken for treatment. After recovery he converted to Islam, married an Afghan girl, and multiplied his family 
there. (ibid). He further says that though he is not affluent in Afghanistan, yet he is happy as in Russia he will either be frowned upon for being a convert or will be considered as rebel. Such stories are amusing to listen to but very difficult, for a sensitive man, to digest. The idea of separation from near and dear ones is soul snatching. Apart from it, the years that are passed with the sweet memories of the papa and mama or the siblings and the childhood friends are a constant trauma for the already psychological disturbed minds of soldiers. The Last Soviet in Afghanistan (RT Documentary, 2016) is another story shared on youtube in which Nekmamat is shown as the soviet soldier living in Afghanistan for the last 30 years with his Afghan wife and children. He visited his homeland after the lapse of thirty years. He is received by the family members with much acclaim and floods of tears and cries. His visit to his parents' graves is heart-wrinching event. Such stories are implicit in Khan's poems related to war.

That war brings nothing but putting rift in the overall smooth-led life of man. It creates distrust and despondence among the affected. War brings death and desaster. It leaves behind the cries of orphans and widows. It takes away shelter and bread. Such themes are abundantly conveyed by Khan through his poetry using foregrounding as a major tool

\section{References}

Abbas, H. (2011). Panel 4: Reevaluating US policy in Afghanistan and Pakistan in 2011. Washington: http://www.mei-edu/events

Ahmad, J. (2012). The Christian Science Monitor. www.cs.monitor.com

Ayres, A. (nd) Conflict between India and Pakistan. Council on Foreign Relations. https://www.cfr.org Retrieved 10 Oct, 2018

Black, J. (2014). The symbol of the Swastika and its 12,000-year-old history. Ancient Origins: Reconstructing the Story of Human's Past. https://www.ancient-origins.net/mythslegends/symbol-swastika-and-its-12000-year-old-history-001312

Black, J. (2014). The symbol of the Swastika and its 12,000-year-old history. http://www.ancientorigins.net/myths-legends/symbol-swastika-and-its-12000-year-old-history-001312Retrieved 27 May, 2018.

Bosnia. www.youtube.com Retrieved 30 April, 2018

DW Documentary. (2018). Bosnia and Herzegovina: an ethnically divided country. https://www.youtube.com/results?search_query=bosnia

Economic Security and Strategic Policy. Regional Studies. (2016). Vol.xxx.No.2, Islamabad. Institute of Regional Studies. , 39-60.

Fukuyama, F. (1982) Pakistan since the Soviet Invasion of Afghanistan. Strategic Studies Institute US Army War College, Carlisle Barracks, Pennsylvania. http://www.dtic.mil/dtic/trRetrievd 24 April, 2017.

Heidtmann, Ho. (1991). "Swastika." In Encyclopedia of the Third Reich, 937-939. New York: Macmillan.

Heller, Steven. The Swastika: Symbol Beyond Redemption? New York: Allworth Press, 2000

Holocaust Encyclopedia, history of Swatika. https://www.ushmm.org/wlc/en/article. Retrieved 11 Jan, 2018

Humble, K (2013). This is the Spice Island history according to Indonesia colonizer history, some true, some are not.The Spice Trail Kate Humble BBC.www.youtube.com. Retrieved 30 April, 2018.

Jaspal, Z. N. (2010). Threat of Extremism and Terrorist Syndicate beyond FATA, P 45. Journal of Political Studies, Vol.1, Issue 2, 19 - 49. 
Javaid, U \& Ali, Z. (2013) War on Terror Partnership: Problems and Prospects for Pakistan. Journal of Political Studies, Vol. 20, Issue - 1, 2013, 51:66. http://pu.edu.pk

Javaid, U. (2013). Pakistan fights extremism and terrorism. Lahore: Vanguard Books.

John R. Lampe (n.d.) The Editors of Encyclopedia Britannica.https://www.britannica.com/ event/Bosnian-conflict Retrieved 11Jan, 2018.

Kamal, D. Khan, H. Azam, I. (1986). Three Voices.Nairang-e-khayal, Rawalpindi.

Kamal, M. (2001). The Taliban Phenomena: Afghanistan 1994-1997. International Journal of Middle East Studies 32: 586-588. https://www.omicsonline.org Retrieved 08 July, 2018

Kande, S. (2010). SUNY Old Westbury. http://exhibitions.nypl.org/africanaage/essay-africa2010.htmlRetrieved 11 Jan, 2018.

Kande, S. (2018). Essay on Poverty in Africa. https://www.google.com.pk

Karim, M. (2017). World Powers Rivalry in Afghanistan and Its Effects on Pakistan. The Dialogue, July-September 2017 Issue. http://www.qurtuba.edu.pk Retrieved 22 Sep, 2017

Kate Humble, K. (2013). The Spice Island History. Maluku Island.Paul Souisa. www.youtube.com

Khan, H. \& Anwar, Z. (2016). Kipling's Depiction of the Great Game between British India and Czarist Russia. Al-Idah 33 (Dec. 2016) http://iri.aiou.edu.pk Retrieved 17 Jan, 2017

Khan, H. (2002). Velvet of Loss. Dr Abdul Malik Book Foundation, Malakand Agency. Atifaq Press Peshawar.

Ku Klux Klan.www.dictionary.com. Retrieved 11 Jan, 2018

Lampe, J.R. (n.d.). Bosnian Conflict. EUROPEAN HISTORY [1992-1995]. https://www.britannica. com/event/Bosnian-conflict

Martindale, C. (2007). Deformation forms the course of literary history. Language and Literature, 16(2), pp. 141-153.

Moss. L. (2014). Corpus Stylistics and Henry James's Syntax. http://discovery.ucl.ac.uk /1461029/1/Lesley_Moss_thesis\%5B1\%5D.pdf Retrieved 15 March, 2016.

Mohammad I (2016) Instability in Afghanistan: Implications for Pakistan. J Pol Sci Pub Aff 4: 213. doi:10.4172/2332-0761.1000213. https://www.omicsonline.org Retrieved 08 July, 2018

Nikolaev, A. (2015). Forever Captive.Bird In Flight Publishers. https://birdinflight.com/ inspiration/project/a-russian-afghani-a-story-of-a-captive-soldier-from-alexey-nikolaev-sbook.html

Nikolaev, A. (2018). Russian Afghans. A Youtube documentary titled as Forever Captive? www.youtube.com. Retrieved 15 May, 2018.

Palestinian-Israel Conflict. http://www.questionsaboutislam.com/history-of-islam/history-palestinianisraeli-conflict.php?print=1 Retrieved 11 Jan, 2018

Questions About Islam. (2007 - 2018).What is the historical background of the Palestinian-Israeli conflict? http://www.questionsaboutislam.com

RT Documentary. (2016). The Last Soviet in Afghanistan. https://www.youtube.com/results?search_ query $=$ The + Last + Soviet + in + Afghanistan +

Safi, S. (2013). Pakistan and Afghanistan then what need to do? Pakistan institute of legislative Development and transparency. https://www.omicsonline.org Retrieved 08 July, 2018. 
Shen, Y. (2007). Language and Literature: Foregrounding in Poetic Discourse. URL: http://lal.sagepub.com

Thakur, R. (2012). A Changing Chessboard: The New Great Game in Afghanistan Global Asia. A Journal of the East Asia Foundation, Seoul. www.globalasia.org

The Last Soviet in Afghanistan. www.youtube.com. Retrieved 16 May, 2018.

van Peer, W. \& Hakemulder, F. (2006). Foregrounding. https://www.researchgate.net/ publication/46690484_Foregrounding . Retrieved 13March, 2017 